\title{
Hereditary neuropathy with liability to pressure palsies
}

INSERM

\section{Source}

INSERM. (1999). Orphanet: an online rare disease and orphan drug data base. Hereditary neuropathy with liability to pressure palsies. ORPHA:640

Hereditary neuropathy with liability to pressure palsies (HNPP) is an inherited peripheral nerve disorder characterized by recurrent mononeuropathy usually triggered by minor physical activities. 